\title{
Hazardous spent methanol synthesis catalyst, bauxite red mud and ground cooled ferrous slag application to produce sustainable ceramics
}

Vsevolod Mymrin ( $\square$ seva6219@gmail.com )

Universidade Tecnologica Federal do Parana - Campus Medianeira

Reinaldo H. G. Alarcon

Marilia A. Guidolin

Walderson Klitzke

Monica A. Avanci

Paulo H.B. Rolim

Karina Q. Carvalho

Rodrigo E. Catai

\section{Research Article}

Keywords: Red mud, Hazardous methanol synthesis catalyst, Steel Slag, Sustainable ceramics, Environment protection

Posted Date: January 31st, 2022

DOI: https://doi.org/10.21203/rs.3.rs-1284970/v1

License: (a) (1) This work is licensed under a Creative Commons Attribution 4.0 International License. Read Full License 


\section{Abstract}

New composites of sustainable ceramic composites from hazardous methanol synthesis catalyst waste, bauxite red mud and ground cooled ferrous slag were developed in this study. The ceramics were sintered at temperatures of $900^{\circ}, 1000^{\circ}, 1050^{\circ}, 1100^{\circ}$ and $1150^{\circ} \mathrm{C}$ for one hour. Almost all ceramic demonstrated fairly high properties, starting from a firing temperature of $1000^{\circ} \mathrm{C}$. The best results were obtained after firing at $1050^{\circ} \mathrm{C}$, which reached $25.98 \mathrm{MPa}$ of flexural resistance, $8.80 \%$ of water absorption, $3.46 \mathrm{~g} / \mathrm{cm}^{3}$ and $7.14 \%$ of linear shrinkage. Studies of physical - chemical processes of the ceramics' structure formation by XRD, SEM / EDS / mapping and LAMMA methods show the synthesis of mainly amorphous new formations with strong glass-like structures. Therefore, the result of leaching and solubility of the initial components' heavy metals in acid environment by the method of atom-absorption spectroscopy indicated their almost complete immobilization, which far exceeded the demands of Brazilian sanitary norms.

\section{Introduction}

Waste production has become a notorious problem in modern society. The degradation of the environment, the contamination of water and soil sources [1], and the eventual compromise of human health becomes evident. Studies refer to the possibility of using waste as alternative components in the manufacturing of different raw material, such as ceramics for civil construction [2]. According to Camargo, et al. [3], the sintering performs the encapsulation and stabilization of hazardous components to leaching. [4] point out that the reuse of residues harmful to health and the environment, transforming them into ceramic products, significantly reduces the impact of the industrial process.

Catalyst, according to [5], is a substance that increases the speed of a reaction without changing the Gibbs total energy variation. The world scientific and technical literature contains a lot of information about the use of various types of catalysts for a large number of very different catalytic processes. The catalysts used in the potential production routes are composed of metals such as cobalt (ethanol production), iron-copper-rubidium in the Fischer-Tropsch process (olefins, gasoline, paraffins and diesel) and copper-zinc-aluminum (methanol production) [6]. Recently, entropy stabilized catalytic systems have been raised great concerns due to the urgent demand for functional materials aiming to realize chemical catalysis [7]. Al-Faze, et al [8] studied dehydration of $\mathrm{MeOH}$ to dimethyl ether at the gas-solid interface in the presence of bulk and SiO2-supported Keggin heteropoly acids. Luo, et al [9] provided an overview of recent processes in using in situ and operando spectroscopy to investigate the relationship between structure and activity/selectivity on oxide-supported metal catalysts and at metal-oxide interfaces. The catalytic oxidation kinetics of three chlorinated hydrocarbons as hazardous waste were determined by Manning [10] in an externally pumped recycle reactor with a commercially available chromia on alumina catalyst. However, the variants of methods for the disposal of waste from catalysis processes are not covered at all in the scientific and technical literature; this fact can only be explained by the absence of these methods. 
Depending on the quality of the bauxite and the technical layout of the Bayer process, between 1.1 and 6.2 tons of red mud are generated per 1 ton of alumina produced. The cumulative stock of red mud in 2000 was around 600 million tons [11], in the world and almost 4 billion tons have already been accumulated till 2021 [12]. Therefore, it is "....one of the biggest challenges for the aluminum industry since its inception" due to "... the risk of releasing of waste into the environment" [13].

This official statement was confirmed by one of the most severe European ecological tragedies in Hungary 2010 with long-term ecological effects [14]. A million cubic meters of the red mud sludge of high alkalinity spilled from a reservoir at an alumina plant in Ajka; 10 people were killed, about 123 persons injured and 790 persons affected [15].

In order to utilize such a large amount of RM and to prevent the recurrence of such disasters, it is necessary to develop the maximum number of economically and environmentally attractive methods of disposal of this dangerous sludge. Therefore, several studies have been published on the use of RM for different purposes: as a catalyst [16]; for mine soil remediation [17]; for treatment of gold ores [17]; as an adsorbent for the removal of toxic pollutants [19]; as a pigment [20].

The study by [21], points out that the addition of $20 \%$ RM in clay promotes an ideal material for bricks manufacturing at $1050^{\circ} \mathrm{C}$. [22] indicates that for the production of bricks, the addition of up to $50 \%$ RM sintered at $950^{\circ} \mathrm{C}$ for one hour, promotes compressive resistance superior to that found in material made only with clay. In a ceramic study, the influence of RM was analyzed by [23] on two different clay bases in the proportions of 0 to $50 \%$ of the waste.

Ferrous slag (FS) is by-product of metallurgical processes of pig iron and different types of steel melting. On average the production of one ton of steel results in average $300 \mathrm{~kg}$ of slag. Global steel production reaches $1870 \mathrm{Mt}$ in 2019, approximately with $620 \mathrm{Mt}$ of slag annual production [24]. In porcelain tiles, [25] developed samples containing more than 30\% FS, obtaining flexural strength of up to 99.84 MPa. Even higher flexural resistance (110 MPa) of glass-ceramic composed of FS, quartz, sand and coal ash presented [26]. Other studies have shown that the use of ES is viable in cement incorporation Tsakiridis et al [27] and in use as an asphalt aggregate [28]. Mymrin [29] developed a new method of FS using as a binder for natural soils, as roads and airports bases material to replace conventional layers of sand and aggregates of natural rocks with very high economic and environmental efficiency.

[30] founded that up to $85 \%$ replacement of clinker by slag is possible without impairing strength of Portland slag cement. [31] mentioned that one of advantages of ground granulated blast furnace slag use is enhancement of the long-term compressive strength, especially after 40 days of curing. But [32], on the contrary, experimentally proved that strength and durability of mortars containing ground granulated blast furnace slag in acid and sulphate environment with slag is lower.

The main objectives of the present study were the following: 1. To develop new ceramics composites from methanol synthesis catalyst, bauxite red mud and ferrous slag without the incorporation of traditional natural raw materials (clay and sand) with enhanced physical-chemical characteristics in 
comparison with Brazilian technical norms; 2. Reliably bind the heavy metals of the initial components of the raw materials to a level significantly lower than the requirements of sanitary standards of Brazil by carrying out the sufficient thermochemical reactions during the sintering of the developed ceramics.

\section{Methods And Raw Materials Characterization 2.1 Methods}

The initial industrial wastes, used as raw materials, and final ceramics, were studied by a complex of modern research methods. To determine the particle size distribution, the sieve method was used. The chemical composition was studied by by XRF on a Philips/Panalytical, model PW 2400; the mineralogical composition - by XRD (Philips, model PW 1830, on $\lambda \mathrm{Cu}$-Ka and the High Score program with the PDF-2 database to interprete the diffractogram patterns). To study the changes of morphological structure was used method SEM (Jeol JSM-6360 LV). Micro-chemical analyses were conducted by EDS method (Jeol JSM-5410 LV). The isotope composition - by the laser micro-mass analyses (LAMMA) method (using a LAMMA-1000, model X-ACT). To study the level of chemical bonding of the chemical elements be the method of lixiviation and solubility in liquid acid environment was applied atomic absorption spectroscopy (FAAS or ICP-OES spectrometer).

The studies of the developed ceramics' mechanical properties changes after sintering at different temperatures were executed by method of three points flexural strength (by EMIC DL-10); water absorption of the ceramics - by the weight increase after 24 hours of their sample's total immersion in water; except, were determined density and linear shrinkage of the ceramics.

All three raw materials were dried at $100^{\circ} \mathrm{C}$ till the constant weight, homogenized in different percentages, with variations of $0-60 \% \mathrm{MSC}, 20-40 \% \mathrm{RM}$ and $0-40 \% \mathrm{FS}$ and hydrated with water content $12-14 \%$. The test samples were compacted at $5 \mathrm{MPa}$ in a rectangular mold of $60 \times 20 \times 10 \mathrm{~mm}$ in size, dried at $100^{\circ} \mathrm{C}$ till the constant weight, and burned for three hours at temperatures of $900^{\circ}, 1000^{\circ}, 1050^{\circ}, 1100^{\circ}, 1150^{\circ} \mathrm{C}$, with a temperature increase speed of $10^{\circ} \mathrm{C}$ per minute, and with spontaneous furnace cooling.

The mechanical properties of the ceramics were replicated at five test samples with calculation of the average and standard deviation. The total quantity of the ceramics' test samples reached till 500 pieces.

\subsection{Calculations}

The study of the linear shrinkage LS (\%) values was conducted in accordance with the equation:

$\mathrm{LS}=\mathrm{Li}=[(\mathrm{Li}-\mathrm{Ls}) / \mathrm{Li}] \times 100(1)$

where $\mathrm{Li}$ - initial length of specimen $(\mathrm{mm})$, and Ls - length of the specimen after the sintering $(\mathrm{mm})$.

Water absorption coefficient $\left(\mathrm{C}_{\mathrm{WA}}\right)$ tests were performed after ceramics' sintering by the following equation: $C_{W A}=\left[\left(M_{S A T}-M_{D}\right) / M_{D}\right] \times 100$ (2) 
where $M_{S A T}$ - the mass of the test samples total water saturation during 24 hours, and $M_{D}$ - the mass of the dry test specimen.

The values of density $\mathrm{D}\left(\mathrm{g} / \mathrm{cm}^{3}\right)$ were calculated by the equation:

$\mathrm{D}=\mathrm{Md} / \mathrm{a} \cdot \mathrm{b} \cdot \mathrm{c}(3)$

Md - weight of the dry sample after firing, a - length of the sample, b - width of the sample,

c - thickness of the sample.

\section{Results}

\subsection{Raw materials characterization}

Three types of industrial wastes - methanol synthesis catalyst (MSC), red mud (RM) from bauxite processing and ferrous slag (FS) - were used as the only raw materials components of the developed ceramics, completely replacing traditional raw materials (natural clay and sand).

The representative sample of RM was received from an aluminum factory in Sao Paulo; ferrous slag was obtained in the steel plant of the company Gerdau, in Curitiba. RM is a residue from the processing of bauxite, in the extraction of $\mathrm{Al}(\mathrm{OH})_{3}$. The annually discarded mass of the MSC on the factory near Curitiba corresponds to forty tons of highly carbonized catalyst.

\subsubsection{Particle size distribution of the raw materials.}

All raw materials were crushed on a jaw crusher, dried till the constant weight at $100^{\circ} \mathrm{C}$, milled in a ball mill and sieved on a sieve $1.14 \mathrm{~mm}$. MSC in the form of cylindrical brilliant granules with a diameter of $0.55 \mathrm{~cm}$ and a height of $0.3 \mathrm{~cm}$ presented in the Fig. $1 \mathrm{a}$ and $\mathrm{b}$.

The RM had $64.51 \%$ moisture, red color and homogeneous consistency. After grinding, the material has a major granulometry of $\leq 0.074 \mathrm{~mm}(72.67 \%)$. The ferrous slag (FS) after milling and magnet separation of molten iron particles contained almost all (98.65\%) particle size between $0.59-0.075 \mathrm{~mm}$ with a major part of them $(66.39 \%)$ had $0.29-0.15 \mathrm{~mm}$ size.

\subsubsection{Chemical composition of the raw materials}

The chemical composition of the MSC determined by RXF method (Table 1) mainly consists of copper oxide (58.2\%), zinc oxide (24.0\%), aluminum oxide (6.0\%). The principal oxides of red mud are $\mathrm{Fe}_{2} \mathrm{O}_{3}$ (29.9\%), $\mathrm{Al}_{2} \mathrm{O}_{3}(21.2 \%), \mathrm{SiO}_{2}(15.5 \%)$ and $\mathrm{Na}_{2} \mathrm{O}(10.3 \%)$, total $76.9 \%$. The ferrous slag mainly consisted of $\mathrm{Fe}_{2} \mathrm{O}_{3}(64.4 \%), \mathrm{SiO}_{2}(13.4 \%), \mathrm{SO}_{3}(9.7 \%), \mathrm{CaO}(2.7 \%)$ and $\mathrm{Al}_{2} \mathrm{O}_{3}(2.5 \%)$. Some researcher $[33,34]$ rather informed similar chemical compositions of ferrous slag. 
Table 1

Chemical composition of the raw materials (by XRF method)

\begin{tabular}{|c|c|c|c|c|c|c|c|}
\hline \multirow[t]{2}{*}{ Oxides } & \multicolumn{3}{|c|}{ Compositions, wt.\% } & \multirow[t]{2}{*}{ Oxides } & \multicolumn{3}{|c|}{ Compositions, wt.\% } \\
\hline & MSC & RM & FS & & MSC & RM & FS \\
\hline $\mathrm{SiO}_{2}$ & 0 & 15.5 & 13.4 & $\mathrm{CaO}$ & $<0.1$ & 4.2 & 2.7 \\
\hline $\mathrm{CuO}$ & 58.2 & 0 & 0.1 & $\mathrm{MgO}$ & 0 & 0.1 & 0.3 \\
\hline $\mathrm{ZnO}$ & 24.0 & $<0.1$ & 0 & $\mathrm{TiO}_{2}$ & 0 & 2.4 & 0.4 \\
\hline $\mathrm{Al}_{2} \mathrm{O}_{3}$ & 6.0 & 21.2 & 2.5 & $\mathrm{P}_{2} \mathrm{O}_{5}$ & 2.0 & 0 & 0 \\
\hline $\mathrm{SO}_{3}$ & 0.3 & 0 & 9.7 & $\mathrm{BaO}$ & 0 & 0 & 0.2 \\
\hline $\mathrm{Fe}_{2} \mathrm{O}_{3}$ & 0.1 & 29.9 & 64.4 & $\mathrm{Cl}$ & 0 & 0.2 & 0.3 \\
\hline $\mathrm{Na}_{2} \mathrm{O}$ & 0 & 10.3 & 0.8 & $\mathrm{Cr}_{2} \mathrm{O}_{3}$ & 0 & $<0.1$ & 0.3 \\
\hline $\mathrm{K}_{2} \mathrm{O}$ & 0.1 & 0.2 & 0.4 & I.L. & 11.3 & 14.4 & 0 \\
\hline Note: I. & $\operatorname{lgn}$ & Los & & & & & \\
\hline
\end{tabular}

The high content of non-bonded chemical element in liquid extract of acid solutions was detected by AAS method. The results (Table 2) showed that leaching of all metals from flotation waste highly exceeded the demands of Brazilian standard sanitary norms [35]: As - in 5 times, $\mathrm{Cr}-2.3$ times, $\mathrm{Cd}-9$ times, $\mathrm{Pb}$ 6 times, $\mathrm{Hg}-22$ times, Se -2 times.

Table 2 - Leaching and solubility of metals from red mud and composition 10 after sintering at $1150^{\circ} \mathrm{C}$. 


\begin{tabular}{|c|c|c|c|c|c|c|c|c|}
\hline \multirow{3}{*}{$\begin{array}{l}\text { Chem. } \\
\text { elements }\end{array}$} & \multicolumn{4}{|c|}{ Leaching, mg/L } & \multicolumn{4}{|c|}{ Solubility, mg/L } \\
\hline & MSC & Co. & Comp. & [35] & MSC & Comp. & Comp. & [35] \\
\hline & & 9 & 10 & & & 9 & 10 & \\
\hline As & 5.12 & 0.27 & 0.18 & 1.0 & 7.40 & $<0.001$ & $<0.001$ & 0.01 \\
\hline Cr total & 11.29 & 0.86 & 1.26 & 5.0 & 18.53 & 0.02 & 0.01 & 0.05 \\
\hline $\mathrm{Ba}$ & 79.13 & 0.86 & 1.22 & 70.0 & 82.15 & 0.02 & 0 & 0.7 \\
\hline $\mathrm{Cd}$ & 4.35 & 0.09 & 0.13 & 0.5 & 9.22 & 0 & 0 & 0.005 \\
\hline $\mathrm{Pb}$ & 6.19 & 0.10 & 0.15 & 1.0 & 8.06 & $<0.01$ & $<0.01$ & 0.01 \\
\hline $\mathrm{Hg}$ & 2.17 & 0.12 & 0.05 & 0.1 & 3.11 & $<0.001$ & $<0.001$ & 0.001 \\
\hline Se & 1.92 & 0.14 & 0.27 & 1.0 & 2.26 & $<0.001$ & $<0.001$ & 0.01 \\
\hline $\mathrm{Al}$ & 2.16 & 0.11 & 0.19 & * & 5.13 & 0.11 & 0.04 & 0.2 \\
\hline $\mathrm{Mn}$ & 3.55 & 0.14 & 0.08 & * & 5.21 & 0.07 & 0.02 & 0.1 \\
\hline $\mathrm{Fe}$ & 23.47 & 0.43 & 0.73 & * & 29.16 & 0.1 & 0.04 & 0.3 \\
\hline $\mathrm{Cu}$ & 7.72 & 0.07 & 0.04 & * & 8.28 & 0.49 & 0.25 & 2.0 \\
\hline $\mathrm{Zn}$ & 6.38 & 0.04 & 0.08 & * & 7.45 & 0.76 & 0.54 & 5.0 \\
\hline
\end{tabular}

A significantly more excess of hazardous chemical elements when comparing with the requirements of the same standards for the solubility of metals: Al - in 25 times, $\mathrm{Mn}$ - in 52 times, $\mathrm{Fe}$ - 97 times, $\mathrm{Cu}$ - 4 times, $\mathrm{Zn}-1.5$, As - 740, $\mathrm{Cr}$ - 371, Ba 117, Cd - 1844 times, Se - in 226 times.

\subsubsection{Mineral composition of the raw materials}

The XRD pattern of MSC (Fig. 2a) show the presence of the crystalline minerals melaconite (CuO), zincite $(\mathrm{ZnO})$ and berlinite $\left(\mathrm{AlPO}_{4}\right)$ with rather high content of amorphous materials. The scale of the intensity of the peaks of crystalline structures of MSC almost reaches 1,500 count per second (I cps), which indicates the bigger quantity of crystalline structures compared to the other two wastes. The highest of them belongs to melaconite and berlinite.

Mineral composition of the bauxite treatment RM (Fig. 2b) is presented by rest of untreated bauxite $\mathrm{Al}_{2} \mathrm{O}_{3} \cdot \mathrm{xH}_{2} \mathrm{O}$, hematite $\mathrm{Fe}_{2} \mathrm{O}_{3}$ and magnetite $\mathrm{Fe}_{3} \mathrm{O}_{4}$ and very small quantity of quartz $\mathrm{SiO}_{2}$. Only two minerals' crystalline peaks at the angles of $20^{\circ}=18^{\circ}$ and $26.5^{\circ}$ have intensities near $700 \mathrm{cps}$ due to coincidence of two minerals' peaks; all other peaks barely exceed the x-ray background line. That means the approximal equality of crystalline and amorphous phase in RM, or even the predominance of the amorphous phase over the crystalline.

Figure 2 
The diffractogram patterns of the of the ferrous slag (Fig. 2c) demonstrate extremely low crystalline peaks (with I cps near 500) and the biggest contain of the amorphous materials. The crystalline materials presented by very small peaks of arsenopyrite (AsFeS), followed by chalcopyrite (CuFeS 2 ), pyrites $\left(\mathrm{CuS}_{2}\right)$ and quartz $\left(\mathrm{SiO}_{2}\right)$. Such a ratio of amorphous and crystalline phases should to lower the melting point of materials, if this will not be hindered by a high copper content (58.2\%) in MSC with a sufficiently high melting point $\left(1084^{\circ} \mathrm{C}\right)$.

\subsubsection{Morphological structure of the raw materials}

The analysis of the MSC sample by SEM method (Fig. 3a), in the magnifications at 5,000 times, presents cloudy conglomerates of irregularly shaped particles of different sizes from 1 to $4 \mu \mathrm{m}$ with deep cracks, apparently due to grinding of the material. The RM sample (Fig. 3b) at the same 5000 times magnification is represented by even smaller particles from 1 to $2 \mu \mathrm{m}$.

These particles have a mainly rounded shapes characteristic typical for amorphous materials and are divided by pores also of various shapes and sizes. The degree of aggregation of these particles is much lower than that of MSC.

Figure 3

The ferrous slag particles after milling are presented (Fig. 3c) by the grains of 40 - $50 \mu \mathrm{m}$ size, with a very dense monolithic structure, apparently due to slag melting in the metallurgical process. After milling the particles are covered by till $0.1 \mu \mathrm{m}$ fine FS dust.

\subsection{Mechanical properties of the developed ceramics}

The values of flexural resistance, linear shrinkage, density and water absorption of the compositions submitted to sintering at $900^{\circ}, 1000^{\circ}, 1050^{\circ}, 1100^{\circ}$ and $1150^{\circ} \mathrm{C}$ were measured and discussed.

\subsubsection{Flexural resistance of the developed ceramics}

It is observed (Table 3 ) that the less flexural resistance at all sintering temperatures had the ceramics 1 and 2 with zero contents of MSC, $70-80 \%$ of red mud and $20-3-\%$ of slag. They continued also the strengthening process at $1100^{\circ}$, while all other ceramics were melted. The highest resistance (25.98 MPa at $1050^{\circ} \mathrm{C}$ ) of the Table 3 at all temperatures had ceramics 10 with the biggest $(70 \%)$ of MSC, $30 \%$ red mud and zero content of slag. The $10 \%$ decreasing of MSC till $60 \%$ with $40 \%$ red mud and with zero content of slag (ceramics 11) causes a resistance decrease at all temperatures. Particularly at $1050^{\circ} \mathrm{C}$ it was $13.05 \mathrm{MPa}$ (twice less, than of the ceramic 10) and continued to gown up till $19.60 \mathrm{MPa}$ at $1100^{\circ}$, in a contrary to ceramic 10 , which resistance began to drop down till $13.97 \mathrm{MPa}$ at $1100^{\circ}$ because of the beginning of excessive melting at $1100^{\circ}$ with complete melting at $1150^{\circ} \mathrm{C}$.

The MSC substitution in the ceramics 11 by $10 \%$ red mud (ceramics 7 ) causes a strong decrease in the resistance of the ceramics at $1050^{\circ}$ and $1100^{\circ} \mathrm{C}$. 
The following substitution in the ceramic 11 of $20 \%$ MSC by $20 \%$ of red mud (ceramic 5) leads to the proximity of the resistance values of the two compared materials, but is accompanied by a decrease in the melting point of ceramics 5 from $1100^{\circ}$ to $1050^{\circ} \mathrm{C}$.

All these facts clearly indicate the principal positive influence of MSC on the flexural resistance of the developed ceramics. The lowest melting point (between $1000^{\circ}$ and $1050^{\circ} \mathrm{C}$ ) had ceramic 4 . A subsequent increase in the amount of red mud to $20 \%$ (ceramic 4) causes the maximum value of all ceramics (12.24 $\mathrm{MPa})$ at $1000^{\circ} \mathrm{C}$ with almost complete melting of these samples at the following temperature $1050^{\circ} \mathrm{C}$.

An increase in the content of red mud till 30\% (ceramic 3) due to a decrease in the number of MSC leads to the lowest strength indices of samples, exceedingly only the ceramics 1 and 2 .

Comparison of ceramics 3 resistance with two other ceramics 4 and 6 with the same $30 \%$ slag content confirmed once more the predominant effect of MSC on the resistance of materials: the highest values of resistance always belonged to ceramics 4 with the greatest (50\%) of MSC.

The second resistance value in Table 3 belongs to ceramics 9 with only $40 \%$ MSC, but with $40 \%$ slag. Other ceramics with $40 \%$ slag content (ceramics 8 ) occupied the third place in resistance $(19.12 \mathrm{MPa})$ at 1050 , and at $1100^{\circ} \mathrm{C}$ it was completely melted.

As a preliminary brief conclusion, it can be said that the ceramics with the highest (70\%) MSC content had the highest strength $(25.98 \mathrm{MPa})$. The resistance values were close were ceramics with the maximum sum of MSC $+F S=40+40=80 \%$ (ceramics 9 ) or $30+40=70 \%$ (ceramics 8 ), significantly exceeding Brazilian standards' demands [36].

The presence of red mud in various quantities did not lead to very high strength values, but it significantly exceeded the requirements of Brazilian standards after sintering at $1000^{\circ} \mathrm{C}$ till melting. In addition, red mud reduced the melting temperature of ceramics: ceramics 4 between $1000^{\circ}$ and $1050^{\circ} \mathrm{C}$, ceramics 3,5 and 8 between $1050^{\circ}$ and $1100^{\circ} \mathrm{C}$.

Table 3 - Flexural resistance of the developed ceramics after sintering at different temperatures. 


\begin{tabular}{|ccccccccc}
\multicolumn{3}{l}{ Compositions (wt. \% ) } & \multicolumn{4}{c}{ Flexural resistence (MPa) after sintering at $\mathrm{T}^{\circ} \mathrm{C}$} \\
\hline $\mathrm{N}^{\circ}$ & MSC & RM & FS & 900 & 1000 & 1050 & 1100 & 1150 \\
\hline 1 & 0 & 70 & 30 & 0.98 & 1.99 & 2.34 & 4.57 & 6.99 \\
\hline 2 & 0 & 80 & 20 & 1.05 & 2.06 & 2.39 & 4.66 & 7.91 \\
\hline 3 & 40 & 30 & 30 & 0.53 & 4.25 & 8.02 & 6.13 & Melt. \\
\hline 4 & 50 & 20 & 30 & 2.77 & 12.24 & 2.11 & Melt & Melt. \\
\hline $5-$ & 40 & 40 & 20 & 1.94 & 9.33 & 13.52 & 6.25 & Melt. \\
\hline 6 & 30 & 40 & 30 & 2.84 & 6.68 & 10.49 & 13.97 & 3.30 \\
\hline $7-$ & 50 & 40 & 10 & 1.30 & 9.22 & 10.28 & 14.40 & 2.83 \\
\hline 8 & 30 & 30 & 40 & 2.47 & 5.79 & 19.12 & Melt & Melt. \\
\hline 9 & 40 & 20 & 40 & 2.79 & 10.12 & 25.59 & 24.12 & Melt. \\
\hline 10 & 70 & 30 & 0 & 1.29 & 10.02 & 25.98 & 13.97 & Melt. \\
\hline 11 & 60 & 40 & 0 & 0.81 & 7.27 & 13.05 & 19.60 & 2.32 \\
\hline
\end{tabular}

Note: Melt. - means complete melting of the test samples.

The standard deviation values of the flexural resistance from the obtained experimental data never exceeded $4 \%$ of the average means.

\subsubsection{Linear shrinkage of the developed ceramics}

The values of the linear shrinkage (LS) of the developed ceramics were increased with increasing of the sintering temperature (Table 4). The ceramics 1 and 2 with zero contents of MSC, especially in ceramics 2 with maximum ( $80 \%)$ of red mud had the less LS after sintering at all temperatures. This fact can be explained by their insignificant compaction during firing ongoing thermochemical processes of the component's interaction, which determines their low resistance $(2.3 \mathrm{MPa})$ at $1100^{\circ} \mathrm{C}$. 
Table 4

- Linear shrinkage of the developed ceramics after sintering at different temperatures.

\begin{tabular}{|lllllllll|}
\hline \multicolumn{3}{|c}{ Composition (wt. \%) } & \multicolumn{5}{c|}{ Linear shrinkage (\%) after sintering at $\mathrm{T}^{\circ} \mathrm{C}$} \\
\hline $\mathrm{N}^{\circ}$ & MSC & RM & FS & 900 & 1000 & 1050 & 11001150 \\
\hline 1 & 0 & 70 & 30 & 1.17 & 1.44 & 1.42 & 2.81 & 4.86 \\
\hline 2 & 0 & 80 & 20 & 1.19 & 1.33 & 1.42 & 2.33 & 4.36 \\
\hline 3 & 40 & 30 & 30 & 3.13 & 7.73 & 8.65 & 10.47 & Melt. \\
\hline 4 & 50 & 20 & 30 & 3.36 & 7.68 & 8.14 & Melt. & Melt. \\
\hline 5 & 40 & 40 & 20 & 3.30 & 10.19 & 11.83 & 13.83 & Melt. \\
\hline 6 & 30 & 40 & 30 & 2.39 & 5.58 & 7.97 & 11.21 & 10.17 \\
\hline 7 & 50 & 40 & 10 & 4.36 & 11.94 & 16.13 & 16.50 & 16.79 \\
\hline 9 & 30 & 30 & 40 & 2.92 & 3.36 & 4.86 & Melt. & Melt. \\
\hline 10 & 70 & 30 & 0 & 5.67 & 15.00 & 17.14 & 17.63 & Melt. \\
\hline 11 & 60 & 40 & 0 & 5.03 & 14.03 & 17.58 & 19.13 & 19.64 \\
\hline
\end{tabular}

The ceramics 10 and 11, with zero ferrous slag content, had the maximum shrinkage values at all temperatures, which confirms the role of slag particles as a skeletal additive. Chemical composition of MSC includes $58.2 \%$ of Cu with melting point $1080^{\circ} \mathrm{C}$ and $24 \%$ of $\mathrm{Zn}$ with melting point $420^{\circ} \mathrm{C}$ (total $82.2 \%$ ). During firing they produces well known alloy called brass with a melting point of $880^{\circ}-950^{\circ} \mathrm{C}$, which depends on the percentage of these two metals. Exactly in this temperature range appeared an increase by 9 times in the flexural resistance of ceramic samples 10 and 11 (Table 3 ) and their linear shrinkage by 3 times (Table 4). The resulting brass can serve as a glue-like mass for $30-40 \%$ of the bauxite sludge of the ceramics 10 and 11 , but also as a flux for its melting.

Therefore, the ceramics 8 and 9 with maximum (40\%) slag contents had the minimum (after ceramics 1 and 2) shrinkage values also at all temperatures. They followed by the ceramics 3,4 and 6 with $30 \%$ slag contents, which are higher than of the ceramics 8 and 9, but significantly less than ceramics 2 with 20\% slag content. Shrinkage values closest to composition 10 and 11 are observed for ceramics 7 with $10 \%$ inclusion of slag.

The standard deviation values of the linear shrinkage were between 3 - 5\%.

\subsubsection{Apparent density of the ceramics after sintering}


The density values of all compositions tended to decrease with increasing firing temperature due to faster weight loss compared with shrinkage samples. And only with excessive melting of the samples the density increased due to the filling of pores with the molten liquid phase and a sharp decrease in the volume of samples. Density values also depend on the percentage of components and mainly of the content of metals, such as $\mathrm{Fe}_{2} \mathrm{O}_{3}, \mathrm{CuO}$ and $\mathrm{ZnO}$.

The minimum values of apparent density (as the flexural resistance and linear shrinkage) had ceramics 1 and 2 with zero contents of catalysator waste. Ceramics 1 had a density slightly higher than ceramics 2 due to the higher ferrous slag content with $64.4 \% \mathrm{Fe}_{2} \mathrm{O}_{3}$ compared with bauxite sludge (29.9\%) $\mathrm{Fe}_{2} \mathrm{O}_{3}$.

Table 5

- Apparent density of the developed ceramics after sintering

\begin{tabular}{|lllllllll|}
\hline \multicolumn{3}{|c}{ Composition (wt. \%) } & \multicolumn{5}{c|}{ Density $\left(\mathbf{g} / \mathrm{cm}^{3}\right)$ after sintering at $\mathrm{T}^{\circ} \mathrm{C}$} \\
\hline $\mathrm{N}^{\circ}$ & MSC & RM & FS & 900 & 1000 & 1050 & 1100 & 1150 \\
\hline 1 & 0 & 70 & 30 & 1.73 & 1.70 & 1.67 & 1.73 & 1.82 \\
\hline 2 & 0 & 80 & 20 & 1.64 & 1.57 & 1.55 & 1.65 & 1.71 \\
\hline 3 & 40 & 30 & 30 & 1.92 & 2.04 & 2.30 & Melt. & Melt. \\
\hline 4 & 50 & 20 & 30 & 2.26 & 2.62 & 2.64 & 3.24 & Melt. \\
\hline 5 & 40 & 40 & 20 & 2.08 & 2.52 & 2.51 & 3.08 & Melt. \\
\hline 6 & 30 & 40 & 30 & 2.12 & 2.25 & 2.32 & 2.53 & 3.09 \\
\hline 7 & 50 & 40 & 10 & 1.95 & 2.45 & 2.45 & 2.37 & 2.76 \\
\hline 8 & 30 & 30 & 40 & 2.12 & 2.20 & 2.29 & 2.44 & 2.83 \\
\hline 9 & 40 & 20 & 40 & 2.25 & 2.47 & 3.00 & 3.14 & 3.42 \\
\hline 10 & 70 & 30 & 0 & 2.44 & 2.63 & 3.46 & Melt. & Melt. \\
\hline 11 & 60 & 40 & 0 & 1.99 & 2.60 & 2.98 & 3.27 & 3.44 \\
\hline
\end{tabular}

The maximum density $\left(3.46 \mathrm{~g} / \mathrm{cm}^{3}\right)$ after firing at all temperatures was found for ceramics 10 due to the highest content (70\%) of MSC with $58.2 \% \mathrm{CuO}$ and $24.0 \% \mathrm{ZnO}$ and $30 \%$ red mud.

The standard deviation values of the apparent density never exceeded $0.3 \mathrm{~g} / \mathrm{cm}^{3}$.

\subsubsection{Water absorption $\left(\mathrm{W}_{\mathrm{ABS}}\right)$ of the ceramics after sintering}

The study of changes in water absorption is of great interest, since this characteristic is an indirect indicator of changes in the open porosity of materials. The value of $\mathrm{W}_{\mathrm{ABS}}$ steadily changes with increasing temperature of ceramics sintering due to the formation of gases during 1 . burnout of the 
organics; 2. sulfur from a slag $(9.7 \%)$ and MSC $(0.3 \%)$, 3. the exit of water from the crystalline structure of bauxite $\mathrm{Al}_{2} \mathrm{O}_{3} \cdot \mathrm{xH}_{2} \mathrm{O}$ (Fig. 2-B). Rather high values of Ignition Loss (I.L., Table 1 ) $-11.3 \%$ of MSC and $14.4 \%$ of RM - confirmed the inevitability of these reactions which are reasons for pores' formation when firing ceramics. But there is still a fourth reason, most effective and difficult to calculate: 4 . gases of the thermo-chemical interaction of the components' mixtures.

Table 6 - Water absorption $\left(\mathrm{W}_{\mathrm{ABS}}\right)$ of the developed ceramics

\begin{tabular}{ccccccccc}
\multicolumn{4}{c}{ Composition (wt. \%) } & \multicolumn{4}{c}{ Water absorption, (\%) after sintering at $\mathrm{T}^{\circ} \mathrm{C}$} \\
\hline $\mathrm{N}^{\circ}$ & MSC & RM & FS & 900 & 1000 & 1050 & 1100 & 1150 \\
\hline 1 & 0 & 70 & 30 & 26.84 & 25.59 & 24.11 & 20.61 & 18.75 \\
\hline 2 & 0 & 80 & 20 & 27.67 & 26.24 & 25.83 & 21.40 & 18.58 \\
\hline 3 & 40 & 30 & 30 & 21.17 & 14.58 & 10.68 & 3.17 & Melt. \\
\hline 4 & 50 & 20 & 30 & 16.69 & 14.51 & 10.76 & Melt. & Melt. \\
\hline $5-$ & 40 & 40 & 20 & 20.79 & 10.21 & 10.46 & 3.18 & Melt. \\
\hline 6 & 30 & 40 & 30 & 18.16 & 13.62 & 11.03 & 8.79 & 4.30 \\
\hline $7-$ & 50 & 40 & 10 & 22.94 & 13.88 & 9.13 & 6.29 & 5.91 \\
\hline 8 & 30 & 30 & 40 & 14.50 & 12.85 & 10.66 & Melt. & Melt. \\
\hline 9 & 40 & 20 & 40 & 13.26 & 10.74 & 8.62 & 6.58 & Melt. \\
\hline 10 & 70 & 30 & 0 & 23.12 & 11.47 & 7.65 & 6.44 & Melt. \\
\hline 11 & 60 & 40 & 0 & 24.08 & 13.56 & 8.05 & 4.87 & 3.39
\end{tabular}

The highest values of $\mathrm{W}_{\mathrm{ABS}}$ belonged to ceramics 1 and 2 with $70 \%$ and $80 \%$ red mud of bauxite processing and $20 \%$ slag, which is the best explanation of so low characteristics of these two ceramics. Ceramics 10 and 11 had the lowest $W_{A B S}$ values at all temperatures prior to the start of excess melting at $1050^{\circ} \mathrm{C}$ due to the maximal ( $70 \%$ and $60 \%$ ) of MSC contents.

The values of standard deviation of water absorption of ceramics after sintering at all temperatures no exceeded $0.4 \%$.

\subsection{Physical-chemical processes of structure formation of the developed ceramics}

To study the physical-chemical processes of structure formation of the ceramics, two compositions were selected - 9 and 10; both of them demonstrates the best resistance (Table 3) before the beginning of the excessive melting, the highest apparent density (Table 5) and the lowest water absorption (Table 6). 

mineral composition too.

\subsubsection{Mineralogical composition of ceramic 9 after firing at temperature $1050^{\circ} \mathrm{C}$}

Comparison of the XRD pattern of the ceramic 9 (Fig. 4) with de XRD pattern of the raw materials (Fig. 2) demonstrate the increase in the intensity of the main peaks from $1400 \mathrm{cps}$ to $2100 \mathrm{cps}$, which indicates, the successful thermochemical destruction of the crystalline lattice of bauxite and its low content in the flotation sludge. On the other hand, it indicates satisfactory conditions for the synthesis of a new mineral albite $\left(\mathrm{NaAlSi}_{3} \mathrm{O}_{8}\right)$ with more intense peak at $20^{\circ}=39.2^{\circ}$ during ceramic 9 sintering at $1050^{\circ} \mathrm{C}$.

Figure 4

Almost all initial minerals of the raw materials disappeared because of thermo-chemical destruction and synthesis of other new minerals, such as magnetite $\mathrm{Fe}_{3} \mathrm{O}_{4}$ due to predominance of $\mathrm{Fe}_{2} \mathrm{O}_{3}(64.4 \%)$ in ferrous slag and $29.9 \%$ in red mud; paramelaconite $\left(\mathrm{Cu}_{4} \mathrm{O}_{3}\right)$ due to $58.2 \% \mathrm{CuO}$ in $\mathrm{MSC}$; zincite $\mathrm{ZnO}$ confirmed by $24.0 \%$ in $\mathrm{MSC}$; albite $\left(\mathrm{NaAlSi}_{3} \mathrm{O}_{8}\right)$ synthesized by the presence of $\mathrm{Al}$ in all components; small peaks of ilmenite $\mathrm{FeTiO}_{3}$ because of the presence of $\mathrm{TiO}_{2}(2.4 \%)$ in $\mathrm{RM}$.

Small decreasing of vertical scale of peaks intensity confirmed de common increase of amorphous phase in the ceramics 10 in comparison with ceramics 9 . It can be one of the reasons of ceramics 10 higher flexural strength and density (Tables 3 and 5 ) at all temperatures before the beginning of excessive melting.

\subsubsection{Morphological structure of ceramic 9 and 10 after sintering at temperature $1050^{\circ} \mathrm{C}$}

Better density of the morphological structure of the ceramics 10 in comparison with the ceramics 9 and after sintering at $1050^{\circ} \mathrm{C}$ was confirmed using SEM method (Fig. $5 a$ and b).

Figure 5

Less quantity of open and closed pores, cracks, more completely molten particles in the structure of the ceramic sample 10 can explain these differences in the properties of the two materials. Practically all pores of the ceramics 10 are closed in a contrary of many deep (black) pores of different configurations and sizes from 1 to $18 \mu \mathrm{m}$ of the ceramics 9 . On the surface of the ceramic sample 9 , unbound particles or insufficiently fused particles are clearly visible, that cannot increase the solidity and strength of the structure, in contrast to the structure of ceramics 10 with a wave of completely molten material. 


\subsubsection{Microchemical composition of the new formations of the ceramics 9 and 10 after sintering at temperature $1050^{\circ}$ \\ C}

Results of EDS microchemical composition analyses of the new formations (Fig. 5) of the ceramics 9 (points $1-3$ ) and 10 (points $4-6$ ) after sintering at temperature $1050^{\circ} \mathrm{C}$ (Table 7) showed very high level of heterogeneity of all nearest points. Mane part of them were differed in the set of chemical elements and their percentage ratio neither within the limits of each ceramic, nor in comparing of these two ceramics.

Table 7 - Microchemical composition of new formations of the ceramics 9 and 10 after sintering at temperature $1050^{\circ} \mathrm{C}$ by EDS method (Figure $5 \mathrm{a}$ and $\mathrm{b}$ )

\begin{tabular}{|lllllllllll|}
\hline Points & \multicolumn{8}{l|}{ Content of chemical elements (wt. \%) in the EDS points } \\
\cline { 2 - 13 } & $\mathrm{Na}$ & $\mathrm{Al}$ & $\mathrm{Si}$ & $\mathbf{S}$ & $\mathrm{Ca}$ & $\mathrm{Ti}$ & $\mathrm{Fe}$ & $\mathrm{Cu}$ & $\mathrm{Zn}$ & Total \\
\hline 1 & 7.22 & 12.46 & 13.39 & 0.62 & 0.83 & 0 & 5.84 & 44.21 & 15.43 & 100.0 \\
\hline 2 & 0 & 1.03 & 0 & 0.85 & 0 & 0 & 1.11 & 97.01 & 0 & 100.0 \\
\hline 3 & 17.28 & 0.86 & 11.10 & 0 & 11.32 & 0 & 1.17 & 26.09 & 32.18 & 100.0 \\
\hline 4 & 15.63 & 1.12 & 2.03 & 4.19 & 0 & 0 & 0.53 & 72.35 & 4.15 & 100.0 \\
\hline 5 & 0 & 0 & 12.53 & 8.74 & 20.01 & 0.53 & 0 & 6.25 & 51.94 & 100.0 \\
\hline 6 & 0 & 20.33 & 6.17 & 0 & 3.04 & 1.07 & 18.28 & 10.52 & 40.59 & 100.0 \\
\hline Max. & 17.28 & 20.33 & 13.39 & 8.74 & 0.01 & 1.07 & 18.28 & 97.01 & 51.94 & \\
\hline Min. & 0 & 0 & 0 & 0 & 0 & 0 & 0 & 6.25 & 0 & \\
\hline
\end{tabular}

These results well explained the complexity of the chemical composition of the initial mixture (Table 1) for the synthesis of new minerals with a perfect crystalline structure at $1050^{\circ} \mathrm{C}$, confirmed by the XRD analysis (Figure 4). Therefore, all the maximum and minimum values of all nine chemical elements of Table 7 have differences from zero to $51.94 \%$ (Zn), or from $6.25-97.01 \%(\mathrm{Cu})$.

\subsubsection{Isotopes' composition of the ceramics 9 after sintering at temperature $1050^{\circ} \mathrm{C}$}

The study of the nearest points of ceramics 9 after firing it at $1050^{\circ} \mathrm{C}$ by the laser micro-mass analyses (LAMMA) method showed a large difference both in the composition of the isotopes and in their quantity (peak intensities). These results confirm both the results of the EDS (Fig. 5 and Table 7), and the results of the XRD (Fig. 4) 


\subsection{Mapping of chemical elements of the ceramic 9 after sintering at $1050^{\circ} \mathrm{C}$}

The method of mapping of the chemical elements on the scanning electron microscopy was used to study their distribution in a ceramic sample 9 after firing at $1050^{\circ} \mathrm{C}$. This analysis made it possible to verify the great irregularity of their position for two possible reasons: 1 . insufficient homogenization of the initial components before compaction and firing; 2 . synthesis of microcrystals during the firing and cooling of the samples, which is confirmed by the results of the XRD (Fig. 4).

Figure 7

The maximum uniformity of distribution stands out for $\mathrm{Ti}$, followed by $\mathrm{Fe}, \mathrm{Ca}$ and $\mathrm{Si}$ the maximum unevenness had - $\mathrm{Al}, \mathrm{Na}, \mathrm{Zn}, \mathrm{Cu}$. But the general irregularity of the chemical element's distribution confirmed the predominant amorphism of the developed ceramic materials.

\subsection{Environmental characteristics of the ceramics 9 and 10 by AAS method}

\subsubsection{Leaching and solubility of the developer ceramics}

Leaching and solubility tests from ceramics 9 and 10 in acid solutions allows to evaluate the effect of thermo-chemical bonding of metals in the process of test samples' firing at $1050^{\circ} \mathrm{C}$ to prevent environmental pollution by the developed ceramics. The values of leaching and solubility is given (Table 2) in comparison with the sanitary standards [35] and initial methanol synthesis catalyst (MSC) used as the most environmentally hazardous component of the ceramics. They leaching of all hazardous chemical elements (Table 2) from ceramics 9 in comparison with MSC decreased in 13 (Se and $\mathrm{Cr}$ ) till $110(\mathrm{Cu})$ times: solubility - in 17 times $(\mathrm{Cu})$ till 4057 times $(\mathrm{Ba})$. Leaching values of the composition 10 decreased in 8 times ( $\mathrm{Cr}$ and $\mathrm{Se}$ ) and till 193 times $(\mathrm{Cu})$; solubility values of the ceramics 10 decreased from 33 times $(\mathrm{Cu})$ till 8218 times $(\mathrm{Ba})$. This comparison confirmed strong chemical bonding (or mechanical capsulation) of all hazardous metals in practically insoluble new mainly amorphous glasslike formations of ceramics during their sintering at $1050^{\circ} \mathrm{C}$. All obtained leaching and solubility values are significantly lower than permissible sanitary norms of Brazil [35].

\subsubsection{Gas emission control results during ceramics sintering (by AAS method)}

Samples of the heat gases were collected during ceramics' sintering at $1275^{\circ} \mathrm{C}$ in the glass filter (Figure 8) with a thickness of $0.45 \mu \mathrm{m}$. The separation of the solid particles deposited on the filter was performed by ultrasound (three hours in an acidic medium) and determined by the AAS method (Table 8).

Table 8 - Gas emission rates during the sintering of the developed ceramic. 


\begin{tabular}{lll} 
Heavy & Contents, & {$[35]$,} \\
metals & $\mathrm{mg} / \mathrm{Nsm}^{3}$ & $\mathrm{mg} / \mathrm{Nm}^{3}$ \\
\hline $\mathrm{Cu}$ & 1.720 & 5.0 \\
\hline $\mathrm{Cd}$ & 0.055 & 0.2 \\
\hline $\mathrm{Pb}$ & 0.313 & 5.0 \\
\hline $\mathrm{Cr}$ & 0.426 & 5.0 \\
\hline $\mathrm{Ni}$ & 0.261 & 1.0
\end{tabular}

\section{Fig. 8}

These results, along with leaching and solubility tests (Table 7), convincingly confirmed the robust bond of heavy metals in insoluble and non-volatile condition.

\section{Conclusions}

1. It was confirmed that hazardous industrial waste used in this research as the raw materials - methanol synthesis catalyst (MSC), red sludge from bauxite processing (RM) and ferrous slag (FS) - can be used as valuable raw materials for production of ceramic materials instead of traditional natural raw materials like clay and sand.

2. The best mechanical and physical properties were obtained with two ceramic compositions: 1. 40wt.\% MSC, $20 \% \mathrm{RM}$ and $40 \% \mathrm{FS}$, and 2. 70\% MSC and 30\% RM. Their flexural resistence reached 25.59 and $25.98 \mathrm{MPa}$ correspondingly after sintering at $1050^{\circ} \mathrm{C}$, linear shrinkage till $7.12 \%$ and $17.14 \%$, apparent density -3.00 and $3.46 \mathrm{~g} / \mathrm{cm}^{3}$ and water absorption $-8.62 \%$ and $7.65 \%$. These properties far exceeded the demands of national Brazilian demands to ceramics materials.

3. It was proved by the complex of XRD, SEM, EDS, LAMMA and chemical elements mapping methods that during the sintering of the ceramics at $1050^{\circ} \mathrm{C}$ the thermochemical dislocation of almost all minerals of the starting components and the synthesis of a small amount of new crystalline minerals occurred. However, the decisive role in the formation of the structure and properties of the developed ceramics is played by amorphous glassy formations, which filled pores of the materials.

4. By the method of atomic absorption analysis of a liquid extract obtained in an acidic medium, it has been established that the developed ceramic materials firmly bind or reliably encapsulate all hazardous elements into an insoluble state. This allows to use them as building materials, and at the end of their service, their demolition waste can be used as crushed stone for the production of new environmentally friendly building materials. This allows the use of a large amount of hazardous industrial waste as a valuable raw material, improving the environment of the industrial region. At the same time, it becomes 
possible to sharply reduce the destruction of unrecoverable natural ties by quarries of natural building materials.

5. The calculation of the economic efficiency of the production of developed materials was not part of the purpose of this study, because each time it depends on many specific local parameters. But from the common sense, the use of free raw materials (hazardous industrial waste) instead of costly natural building material is always much more profitable.

\section{Declarations}

\section{ACKNOWLEDGEMENTS}

The authors bring their heartfelt thanks to the Brazilian Aluminum Association, to Votorantim, who provided raw materials for the development of this study; to Laboratory of Minerals and Rocks Analyses (LAMIR - UFPR); and to the Laboratory of Electron Microscopy of Federal University of Technology (UTFPR) for technical assistance in conducting of analyses of this research.

\section{Conflicts of interest and others Declarations}

a. Funding (information that explains whether and by whom the research was supported)

b. We declare absence any conflicts of interest

c. Data and material are available

d. Code availability (software application or custom code) not applicable

e. Ethics approval (include appropriate approvals or waivers) not applicable

f. We show informed consent and provide assurances that participants' rights are protected

g. All co-authors are consent for publication

h. Authors' contributions

Vsévolod Mymrin - author of the idea, developer of the plan of the experiments, participant of all stages of the research, corresponding author

Reinaldo H. G. Alarcon - samples formation and performer of XRD analyses

Marilia A. Guidolin - samples formation and performer of SEM analyses

Walderson Klitzke - samples sintering and gas emission control co-author of this manuscript

Monica A. Avanci - performer of all laboratory experimental works, co-author of this manuscript 
Paulo H.B. Rolim - performer of all types of laboratory experimental works, performer of LAMMA analyses, co-author of this manuscript.

Karina Q. Carvalho - bibliographic studies, performer of all types of laboratory experimental works, coauthor of this manuscript.

Rodrigo E. Catai - bibliographic studies, performer of all types of laboratory experimental works, co-author of this manuscript.

Vsévolod Mymrin

Corresponding author

\section{Referencies}

[1] Menezes RR, et al. (2002) The state of the art on the use of waste as alternative ceramic raw materials. Brazilian J Agric Env Eng, Campina Grande 6: 303-313.

[2] Mymrin V., et al. (2022) Environmentally clean ceramics manufacture with the application of hazardous car production sludge and galvanic process glass waste. J Adv Man Tech. doi: $10.1007 / \mathrm{s} 00170-021-08341-3$

[3] Camargo AC, et al. (2005) Addition of toxic metals to ceramic masses and evaluation of their stability against leaching agent. Part 1: assessment of physical characteristics. J Ceram Ind 10, 39-46.

[4] Tang Y, et al. (2011) Copper stabilization via spinel formation during the sintering of simulated copperladen sludge with aluminum-rich ceramic precursors. J Envir Sci Tech 45: 3598-3604.

[5] Mcnaught AD, Wilkinson A (1997) IUPAC - Compendium of Chemical Terminology (the "Gold Book"). Oxford: Blackwell Scientific Publications. ISBN 0-9678550-9-8. doi:10.1351/goldbook.C00876.

[6] Coutinho J P, et al. (2011) Evaluation of the ceramic catalyst ZnAl2O4 in the ransesterification reaction for biodiesel production. In: 55th Brazilian Ceramics Congress, 2011, Porto de Galinhas. Proceedings of the 55th Brazilian Ceramics Congress. São Paulo: Metallum Technical and Scientific Events.

[7] Gao et al Y (2022) High-entropy oxides for catalysis: Status and perspectives J App Catal A: General 631:118478. https://doi.org/10.1016/j.apcata.2022.118478

[8] Al-Faze R, et al (2020) Dehydration of methanol and ethanol over silica-supported heteropoly acids in the gas phase: Surface-type versus bulk-type catalysis mechanism. J App Catal A: General, 597:117549. https://doi.org/10.1016/j.apcata.2020.117549

[9] Luo L, et al (2021) Heterogeneous catalysis at metal-oxide interfaces using in situ and operando spectroscopy: From nanoparticles to single-atom sites. J App Catal A: General 624: 118330. 
[10] Manning MP (2009) Fluid Bed Catalytic Oxidation: An underdeveloped hazardous waste disposal technology. J Haz Waste 1. https://doi.org/10.1089/hzw.1984.1.41

[11] Hausberg J, et al (2000) Global red mud reduction potential through optimized technologies and ore selection. J Min Res Eng 9: 407-420. https://doi.org/10.1142/S0950609800000354

[12] Aung HY, et al (2021) Current key options for management of industrial alkaline waste of alumina production (red mud) E3S Web Conf. 284, Topical Problems of Green Architecture, Civil and Environmental Engineering (TPACEE-2021). https://doi.org/10.1051/e3sconf/202128401003

[13] Al Circle's - Red Mud (Bauxite Residue) Management: Storage \& Valorization, Report, 2019. https://www.alcircle.com/specialreport/314/red-mud

[14] Winkler D, et al (2018) Long-term ecological effects of the red mud disaster in Hungary: Regeneration of red mud flooded areas in a contaminated industrial region. J Sci Total Env, 644: 1292-1303. https://doi.org/10.1016/j.scitotenv.2018.07.059

[15] Kátai-Urbán L (2010) Disaster in the Ajka red sludge reservoir on 04 October 2010. https://www.unece.org/fileadmin/DAM/env/documents/2010/teia/presentations/5-1Conference _UNECE_Hungary_red_mud_disaster_CD.pdf

[16] Ordóñez S, et al (2001) Characterization and deactivation studies of sulfide red mud used as catalyst for the hydro-dechlorination of tetrachloroethylene. J Appl Catal B: Envir 29:263-273.

[17] Gray CW, et al. (2006) Field evaluation of in situ remediation of a heavy metal contaminated soil using lime and red-mud. J Env Poll 142:530-539.

[18] Browner RE (1995) The use of bauxite waste mud in the treatment of gold ores. Hydrometallurgy 37:339-348.

[19] Bhatnagar A et al (2011) A review of the use of red mud as adsorbent for the removal of toxic pollutants from water and wastewater. Env Tech 32:231-249.

[20] Pera J, et al (1997) Development of a pozzolanic pigment from red mud. J Cem Con Res 27: 15131522.

[21] $\mathrm{He} \mathrm{H}$, et al (2012) The effect of incorporation of red mud on the properties of clay ceramic bodies. App. Clay Sci 70: 67-73.

[22] Pérez-Villarejo L, et al (2012) Manufacturing new ceramic materials from clay and red mud derived from the aluminum industry. J Con Build Mat 35:656-665. DOI 10.1016/j.conbuildmat.2012.04.133 
[23] Sglavo VM, et al (2014) Alumina polymorphs affect the metal immobilization effect when beneficially using copper-bearing industrial sludge for ceramics. J Chemosphere 117:575-581

[24] Global slag (2020) Displaying items by tag: World Steel Association. https://www.globalslag.com/news/itemlist/tag/World\%20Steel\%20Association

[25] Zhao L-H, et al (2015) Synthesis of steel slag ceramics: chemical composition and crystalline phases of raw materials. Int J Min Met Mat 22:325-333.

[26] Liu ZB, et al. (2014) Effect of ( $\mathrm{CaO}+\mathrm{MgO}) / \mathrm{SiO} 2$ ratio on crystallization and properties of slag glass ceramics. J Adv App Ceram 113:411-418.

[27] Tsakiridis PE, et al (2008) Utilization of steel slag for Portland cement clinker production. J Haz Mat 152: 805-811.

[28] Ahmedzade P, Sengoz B (2009) Evaluation of steel slag coarse aggregate in hot mix asphalt concrete. J Haz Mat 165: 300-305.

[29] Mymrin V (1986) Theoretical bases of clay soils strengthening by dumped ground cooled ferrous slags for road base construction. DSc thesis, Moscou State University, 1986.

[30] Kumar A, Kumar S (2013) Development of paving blocks from synergistic use of red mud and fly ash using geopolymerization. J Con Buil Mat 38: 865-871.

[31] Özbay E, et al. (2016) Utilization and efficiency of ground granulated blast furnace slag on concrete properties-A review. J Con Build Mat 105: 423-434,

[32] Łukowski P, Salih A (2015) Durability of mortars containing ground granulated blast-furnace slag in acid and sulphate environment. J Procedia Eng 108:47-54.

[33] Oliveira G E, Holanda JNF (2004) Use of mix of clay / solid waste from steel Works for civil construction materials. J Waste Man Res 22:358-363.

[34] Wendling $L$, et al (2009) Characterization of mining and industrial by-products with potential for use as environmental amendments. CSIRO: Water for a Healthy Country National Research Flagship Report. CSIRO: Perth, Western Australia. $112 \mathrm{p}$.

[35] NBR 10.004: Solid waste - Classification. Rio de Janeiro, 2004.

[36] NBR 15.270-2: Ceramic components. Part 2: Ceramic blocks for structural and sealing masonry Terminology and requirements. Rio de Janeiro, 2005.

\section{Figures}




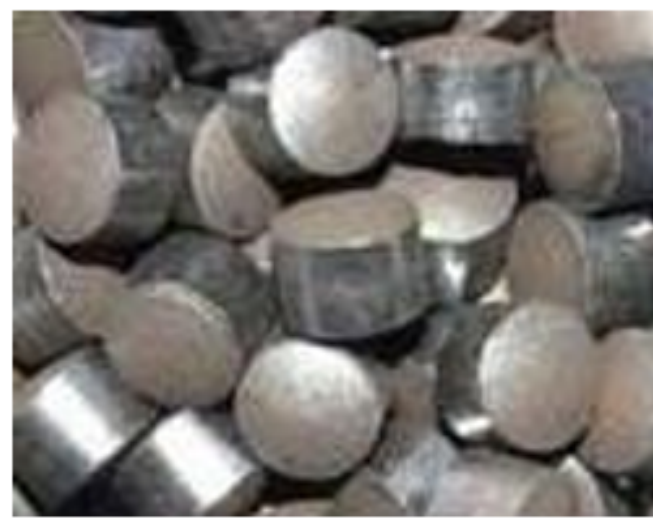

$\mathbf{a}$

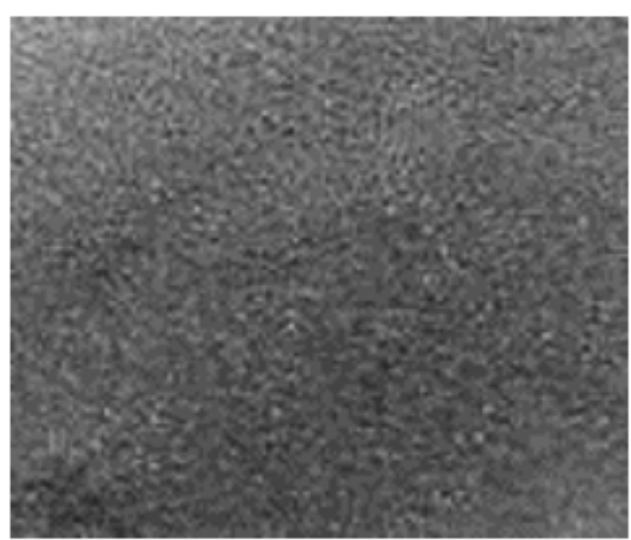

b

Figure 1

Appearance of the waste of methanol synthesis catalyst:

a - original; $\mathbf{b}$ - dry and milled. 


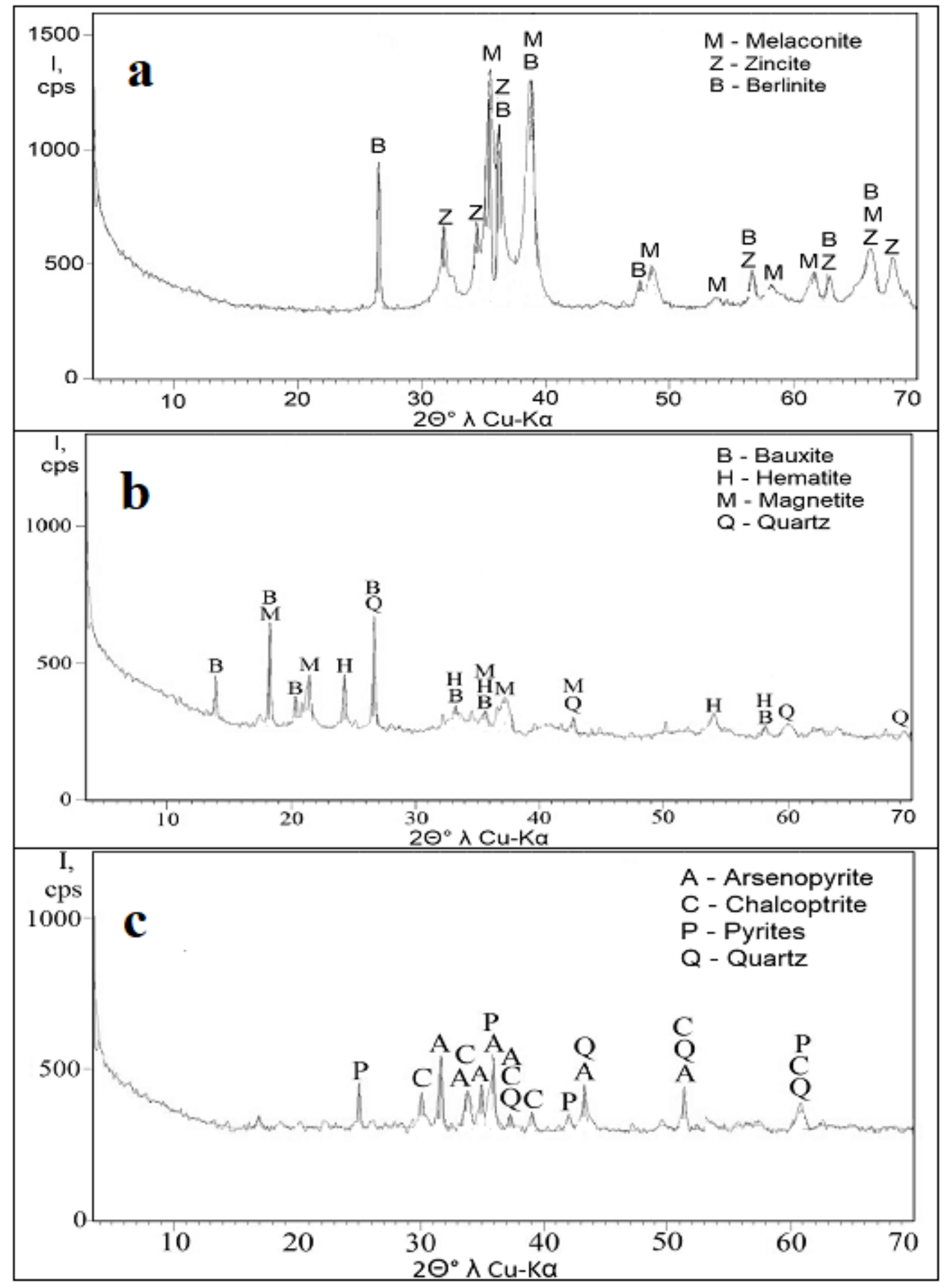

Figure 2

Diffractogram patterns of the raw materials:

a - Waste of methanol synthesis catalyst, b- Red mud, c - Ferrous slag. 


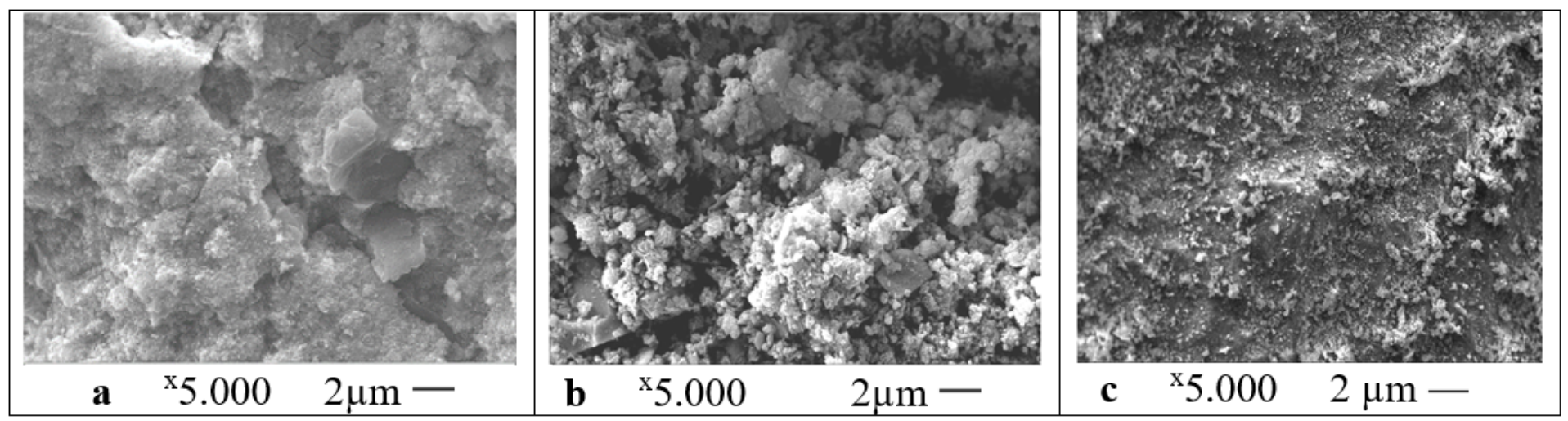

Figure 3

Morphological microstructures of the raw materials:

a - Waste of methanol synthesis catalyst, b - Red mud, c - Ferrous slag.

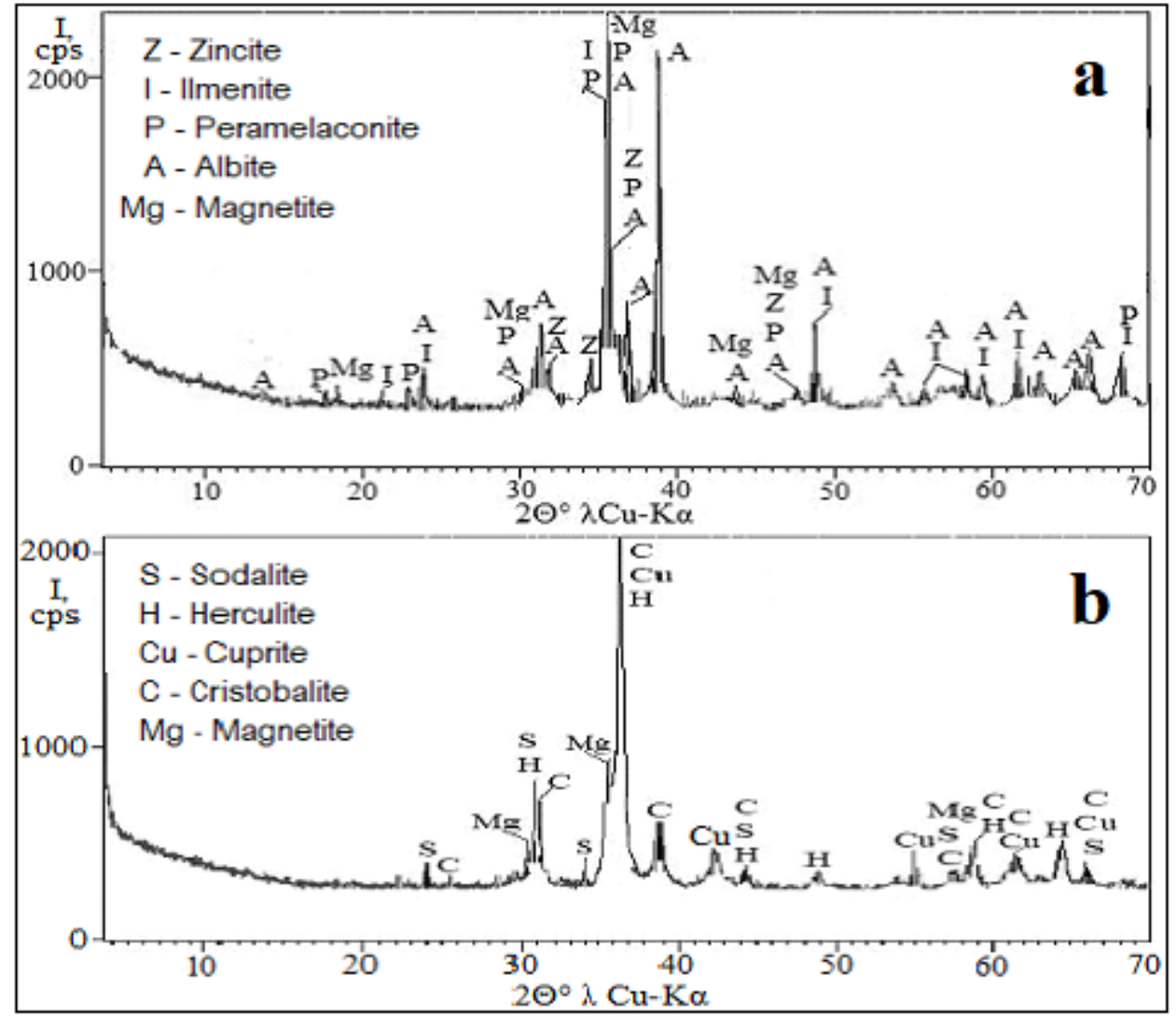

Figure 4

XRD patterns of the ceramics 9 (a) and 10 (b) after sintering at $1050^{\circ} \mathrm{C}$ 


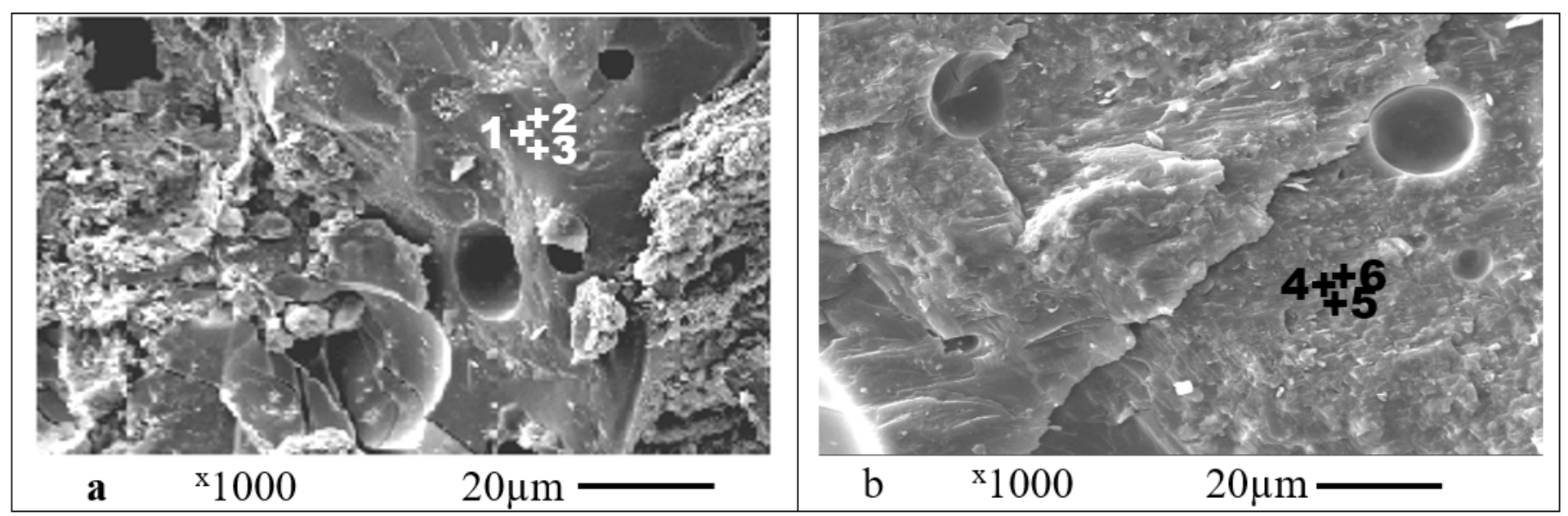

Figure 5

Morphological structure of the composites 9 (a)

and 10 (b) sintered at $1050^{\circ} \mathrm{C}$ and points of EDS analyses

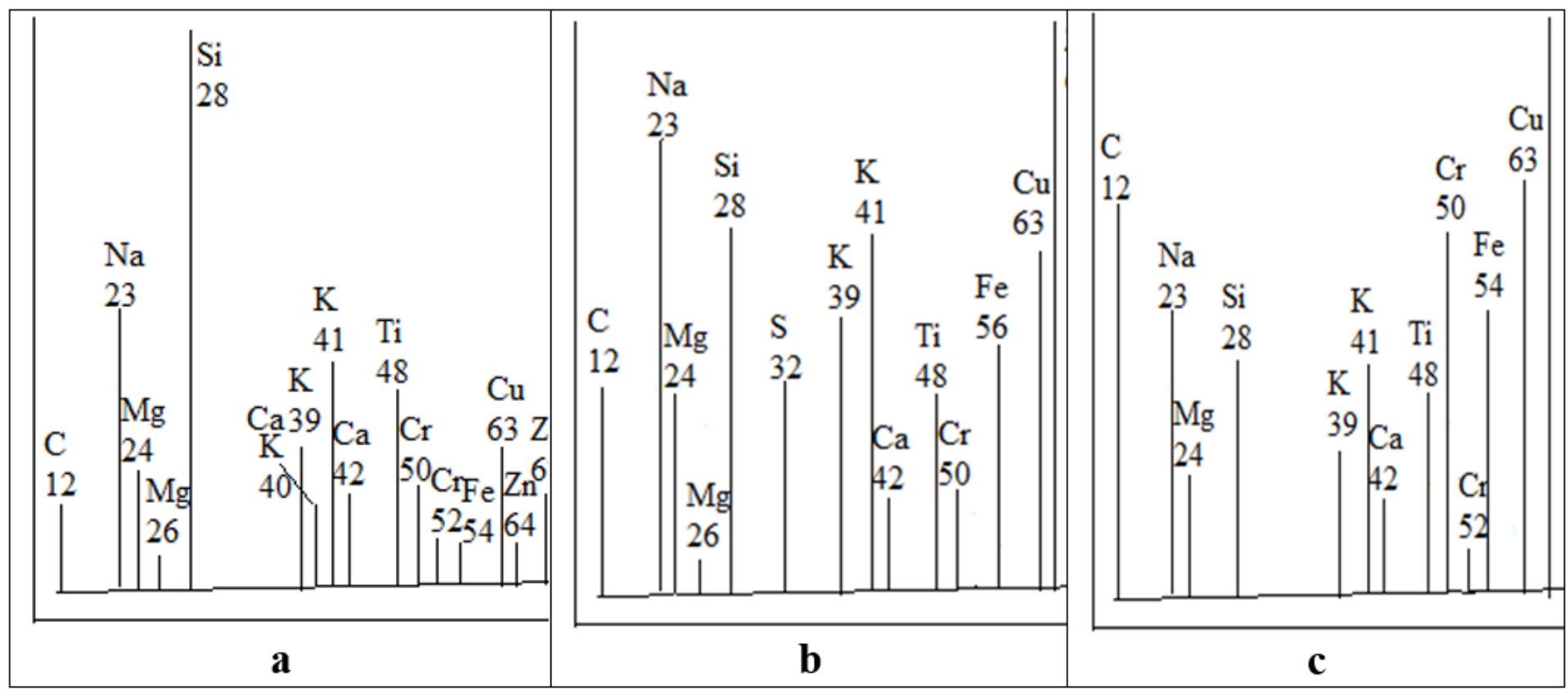

Figure 6

Isotopes' composition of the nearest points of the ceramics 9 . 

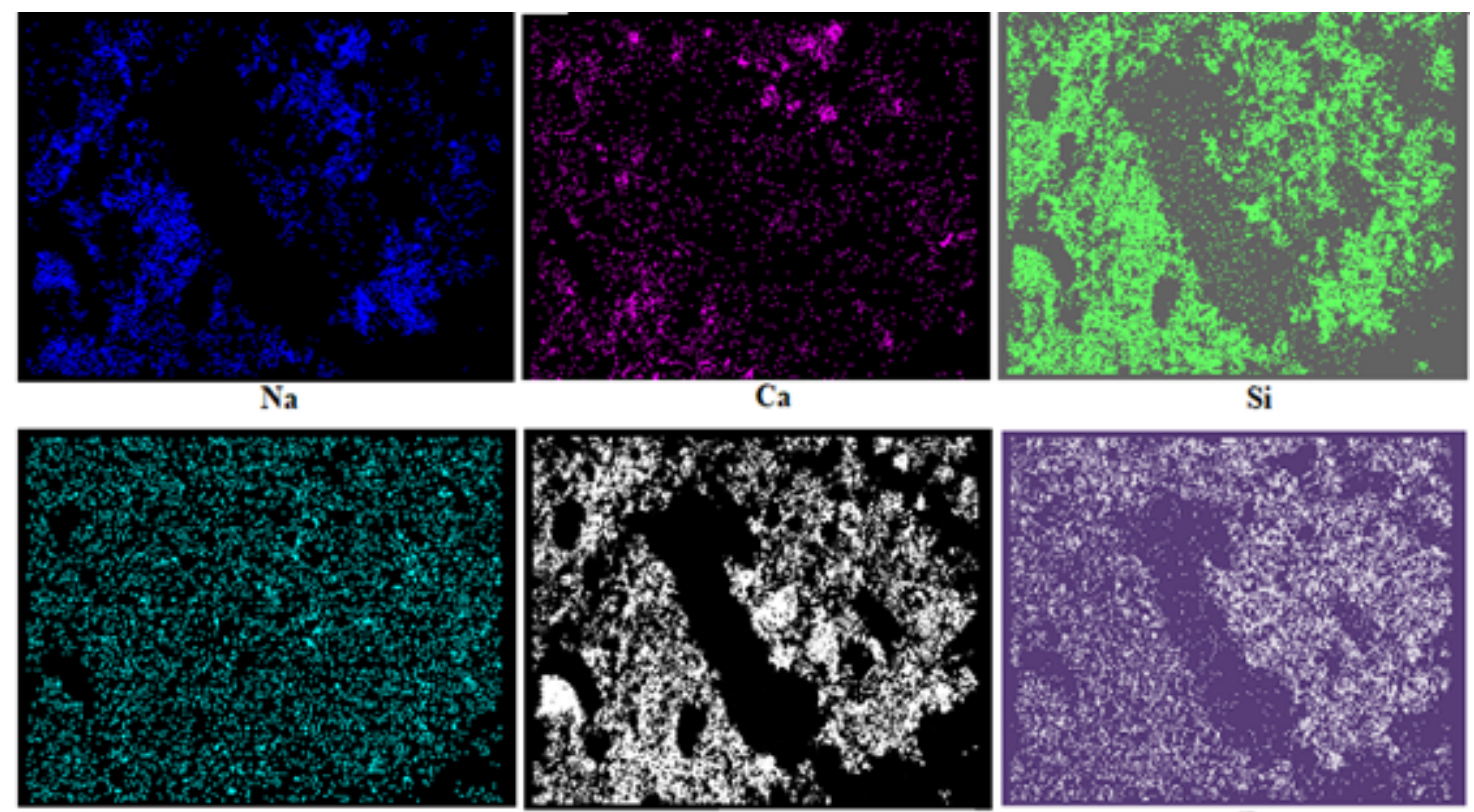

Ca

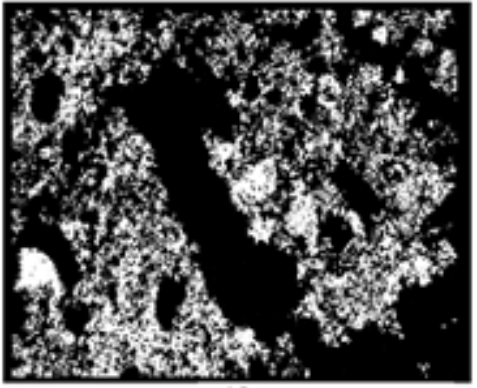

Al
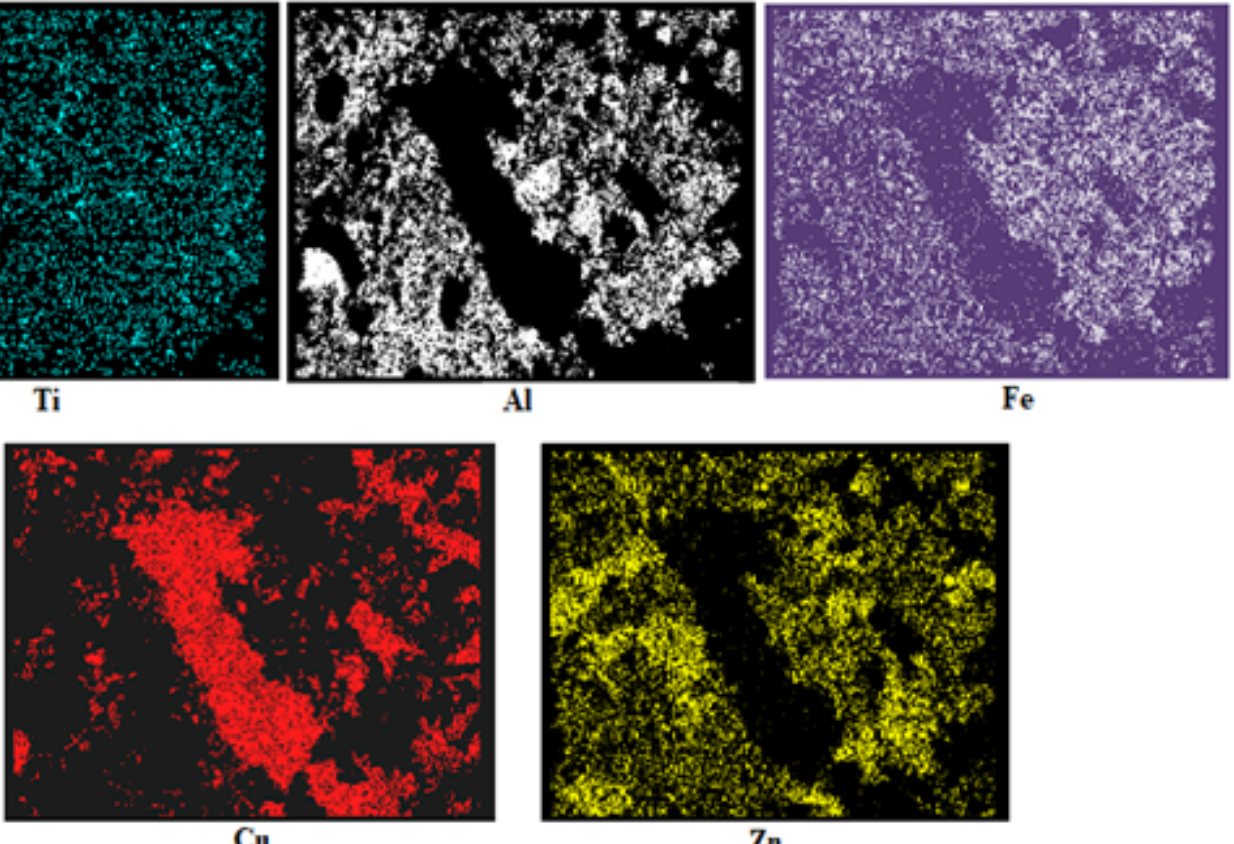

Figure 7

Mapping of chemical elements of the ceramic 9 after sintering at $1050^{\circ} \mathrm{C}$ 


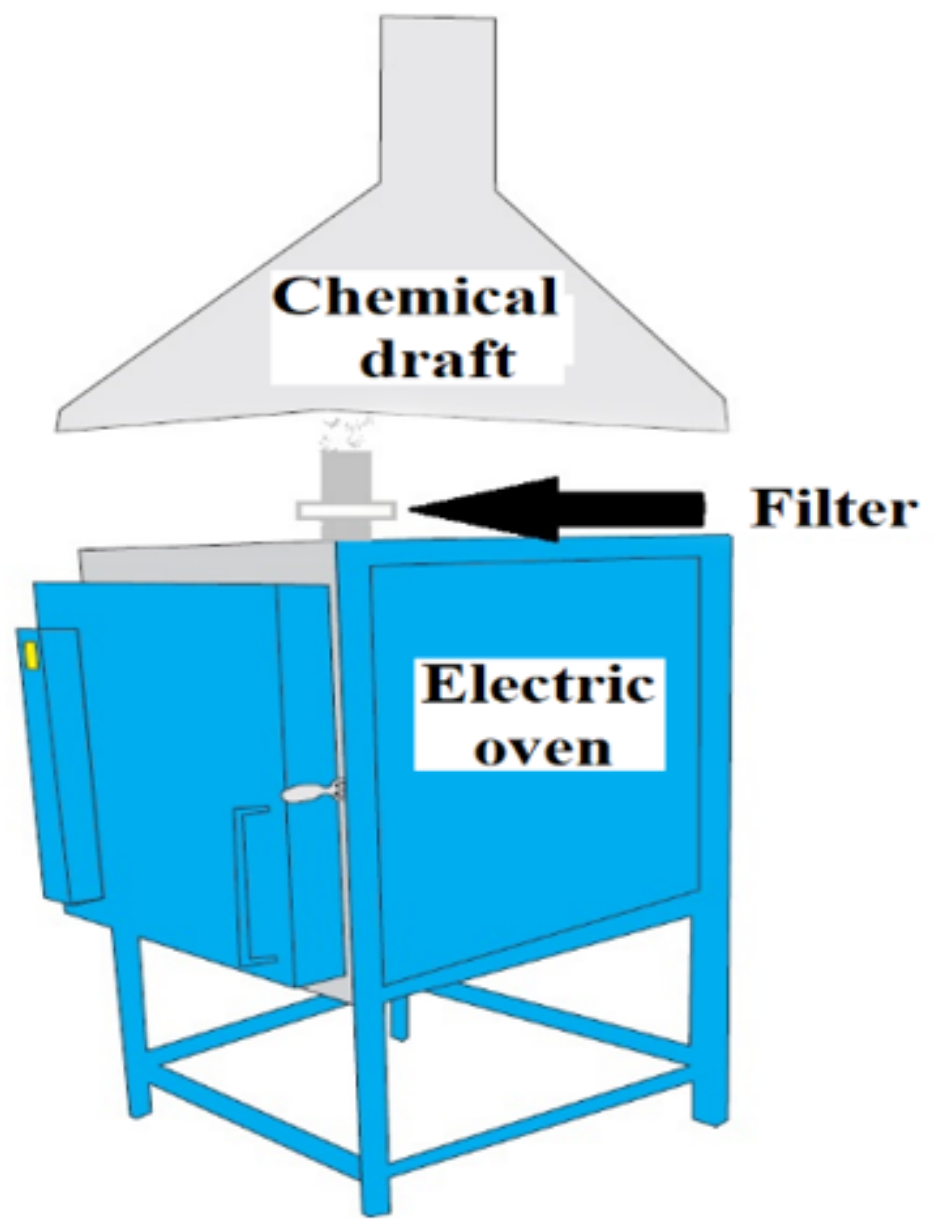

Figure 8

Electric oven with gas filter. 